\title{
Representative benthic habitat mapping on Lovina coral reefs in Northern Bali, Indonesia
}

\author{
ANGGITA KARTIKASARI`, TODHI PRISTIANTO, RIZKI HANINTYO, EGHBERT ELVAN AMPOU, \\ TEJA ARIEF WIBAWA, BERTA BERLIAN BORNEO \\ Institute for Marine Research and Observation, Ministry of Marine Affairs and Fisheries. Jl. Baru Perancak, Jembrana 82218, Bali, Indonesia.
} Tel.: +62-365-44266, Fax.: +62-365-44278, `email: anggita.kartika12@gmail.com

Manuscript received: 25 March 2021. Revision accepted: 13 October 2021.

\begin{abstract}
Kartikasari A, Pristianto T, Hanintyo R, Ampou EE, Wibawa TA, Borneo BB. 2021. Representative benthic habitat mapping on Lovina coral reefs in Northern Bali, Indonesia. Biodiversitas 22: 4766-4774. Satellite optical imagery datasets integrated with in situ measurements are widely used to derive the spatial distribution of various benthic habitats in coral reef ecosystems. In this study, an approach to estimate spatial coverage of those habitats based on observation derived from Sentinel-2 optical imagery and a field survey, is presented. This study focused on the Lovina coral reef ecosystem of Northern Bali, Indonesia to support deployment of artificial reefs within the Indonesian Coral Reef Garden (ICRG) programme. Three specific locations were explored: Temukus, Tukad Mungga, and Baktiseraga waters. Spatial benthic habitat coverages of these three waters was estimated based on supervised classification techniques using $10 \mathrm{~m}$ bands of Sentinel-2 imagery and the medium scale approach (MSA) transect method of in situ measurement.The study indicates that total coverage of benthic habitat is 61.34 ha, 25.17 ha, and 27.88 ha for Temukus, Tukad Mungga, and Baktiseraga waters, respectively. The dominant benthic habitat of those three waters consists of sand, seagrass, coral, rubble, reef slope and intertidal zone. The coral reef coverage is 29.48 ha (48\%) for Temukus covered by genus Acropora, Isopora, Porites, Montipora, Pocillopora. The coverage for Tukad Mungga is 8.69 ha (35\%) covered by genus Acropora, Montipora, Favia, Psammocora, Porites, and the coverage for Baktiseraga is 11.37 ha (41\%) covered by genus Montipora sp, Goniastrea, Pavona, Platygyra, Pocillopora, Porites, Acropora, Leptoseris, Acropora, Pocillopora, Fungia. The results are expected to be suitable as supporting data in restoring coral reef ecosystems in the northern part of Bali, especially in Buleleng District.
\end{abstract}

Keywords: Benthic habitat, coral reefs, Sentinel-2, supervised classification

\section{INTRODUCTION}

The island of Bali is one of the major tourist destinations in Indonesia. In 2018, the number of domestic tourists reached $9,757,991$ people, and the number of foreign tourists was $6,070,473$ people according to the latest report from the Central Statistics Agency of Bali Province. One of Bali's contributions in increasing Indonesia's foreign exchange comes from the marine tourism sector. Bali has $593 \mathrm{~km}$ of coastline and natural beauty under the sea that spoils the eye, making it one of Indonesia's best beach destinations. It is in the southwest corner of the Coral Triangle, an area with the highest marine diversity in the world. The Coral Triangle (CT) Region is situated along the equator between the Indian and Pacific Oceans (Asaad et al. 2018). Bali boasts a high diversity of aquatic ecosystems, one of which is the coral reef. The report from Bali Province Bapedal stated that the coral reefs are distributed nearly along the coast of Bali. Coral reefs provide important ecosystem services to many coastal communities and small island developing states located in tropical and subtropical climes (Saul et al. 2015).

The condition of coral reefs in Northern Bali is relatively better than those in Southern Bali, thanks to the better water quality. The physical and chemical conditions of the waters on the White Sand Island of Sumberkima
Village, for example, have values that support coral reefs to develop optimally (Wicaksono et al. 2019).

Buleleng District is in the northern part of Bali Island. It has an area of $1,365.88 \mathrm{~km}^{2}$ with approximately $144 \mathrm{~km}$ beach length covering 7 districts at several locations along the coast. The Lovina area is one of the famous marine tourism destinations in Buleleng. Most of the coral reefs in the Lovina area are categorized as fringing coral reefs, which are coral reefs that live along the coast (Prasetia and Dodik 2011). The advantage of this fringing coral reef formation is that it can protect against the threat of abrasion due to wave energy and the potential for biota associated in it. The negative impact of fringing coral reef formations is that it can disrupt the coral reef ecosystem's sustainability because human activities easily degrade it. The Condition of live coral coverage in the Lovina, wich includes Tukad Mungga, Baktiseraga, Banyuasri, Anturan and Kalibukbuk, ranges from 18 to $44 \%$ live coral coverage with poor to moderate category. To conserve coral reefs, continuous monitoring is needed. This monitoring can be done spatially by utilizing remote sensing techniques (Ampou 2018).

Remote sensing technology can be used for natural resources mapping studies, such as the shallow water habitat mapping. Several methods used in this technology are satellite image remote sensing (Table 3) and acoustic remote sensing as done by Trzcinska et al. (2020), and 
using multi-beam echo sounder data for benthic habitat mapping as done by Porskamp et al. (2018) and Menandro et al. (2020). Remote sensing techniques have been used successfully to map coral reef habitats at various spatial scales and levels of detail (Roelfsema et al. 2013). While not as detailed as in-situ surveys, remote sensing provides a valuable complementary monitoring approach, where manual surveys would be prohibitively expensive (Hedley et al. 2016). Benthic habitat mapping of coral reefs ecosystems in particular provides important information for scientists and managers about the distribution and extent of reef landscapes (Leon and Woodroffe 2011). In the scope of remote sensing, "shallow water" is defined by the ability of satellite images to penetrate the water column and see the seafloor. Optical remote sensing can be used to map shallow waters that are relatively clear (Green et al. 2000). This technique utilizes the visible spectrum, which has 0.4 $\mu \mathrm{m}$ to $0.7 \mu \mathrm{m}$. In relatively clear shallow waters, optical remote sensing methods can detect water depths between 15-20 m (Mumby et al. 2003). Satellite imagery such as Landsat, Aster, ALOS-AVNIR, Quickbird, Worldview, SPOT-4, Landsat 7 ETM+, and Sentinel-2 can be used to detect shallow water objects. Previous research related to mapping shallow waters (coral reefs) using remote sensing techniques conducted by Ampou in 2018, succeeded in mapping benthic habitats in the coral reef ecosystem in Menjangan using high-resolution imagery, namely Worldview imagery. High spatial resolution offers substantial benefits, and this kind of data is widely used for one-off or occasional reef mapping exercises at local scales (Yamano et al. 2013). One of the limitations of using highresolution imagery is the low temporal resolution, and that it is paid or not an open source. Another study with the same method was conducted by Roelfsema et al. (2018) who successfully mapped the coral reef habitat in Capricorn Bunker Group Reefs, Southern Great Barrier Reef, Australia using landsat 8 OLI. Research conducted by Hedley et al. (2018) has also succeeded in mapping benthic habitats on Lizard Island using Sentinel 2A and Landsat 8.

The Sentinel-2 satellite is a generational satellite designed by the European Space Agency (ESA) for earth observation with open-source data that are freely accessible. Sentinel 2 does have better ability for discrimination of reef benthic composition over SPOT-4 and Landsat ETM+ (Hedley et al. 2012). Hedley et al. (2018) confirmed that Sentinel-2 has excellent performance to meet several scientific and monitoring objectives for coral reefs. Sentinel-2 has a resolution of 10 meters. Sentinel-2 is a multispectral instrument (MSI) platform with data composed of 13 band that can be used as a solution for mapping shallow-water objects, such as coral reefs, seagrass, and bottom substrates.

Research related to coral reef monitoring using Sentinel-2 satellite imagery has been carried out in several locations in Bali. However, there has been no study on coral reef mapping using Sentinel-2 imagery in the Lovina waters area, which includes Temukus waters, Tukad Mungga. And Baktiseraga. This study aimed to map benthic habitats in coral reef ecosystems in Lovina Waters, particularly those in Temukus, Tukad Mungga and Baktiseraga waters. The results are expected to be suitable as supporting data in restoring coral reef ecosystems in the northern part of Bali, especially in Buleleng District.

\section{MATERIALS AND METHODS}

\section{Study area}

This research was conducted in Lovina Waters, Buleleng District, Bali, Indonesia, covering Temukus Waters, located at positions $8.159^{\circ} \mathrm{S}-8.169^{\circ} \mathrm{S}$ and $115.001^{\circ} \mathrm{E}-115.014^{\circ} \mathrm{E}$, Tukad Mungga Waters located at positions $8.134^{\circ} \mathrm{S}-8.143^{\circ} \mathrm{S}$ and $115.048^{\circ} \mathrm{E}-115.054^{\circ} \mathrm{E}$ and Baktiseraga waters, located at positions $8.114^{\circ} \mathrm{S}-8.124^{\circ} \mathrm{S}$ and $115.061^{\circ} \mathrm{E}-115.072^{\circ} \mathrm{E}$ (Figure 1).

This research location is recommended in a major government project, namely Pemulihan Ekonomi NasionalIndonesia Coral Reef Garden (PEN-ICRG). Field data collection was carried out 2 times in field surveys, on 9 October 2020 at Temukus 2 points and 1 point each on 10 October 2021 in Tukad Mungga and Baktiseraga (Figure 1). The tools used to collect field data in this study were the global positioning system (GPS), SCUBA (Self Contained Underwater Breathing Apparatus), diving slate, and underwater cameras. The tools used for data processing were, ArcGIS version 10.6 software, and the Sentinel application platform (SNAP) software version 7.0. The material used in this study is the image of Sentinel-2A level $1 \mathrm{C}$ resolution 10m acquired on August 25, 2020, via the European space agency data hub scientific web at https: //scihub.copernicus.eu.

\section{Procedures}

The data processing procedure is carried out in two stages, namely pre-image processing, and image processing (Figure 2). Image pre-processing is carried out by atmospheric correction, image cropping, deglinting and masking clouds and land. Atmospheric correction is performed to improve the quality of the image due to disturbances in the atmosphere, such as scattering effect. The atmospheric corrected image is then cut or cropped according to the research area to limit the research area and facilitate data analysis. We proceed with the deglint process to eliminate the disturbing effect caused by reflecting sunlight on sea waves. This deglint process uses the method applied by Hedley et al. (2005), which refines the method applied by Hochberg (2003).

This was followed by the masking process to separate the object of study from those not included in the observation, such as the separation of clouds, land, and deepwater areas. The deep-sea separation masking process is done by digitizing the boundaries of the deep sea and shallow sea areas manually. The cloud and land masking processes are performed automatically by utilizing the Land-Cloud-White-cap-Mask Processor tool in the SNAP software https://step.esa.int. This process is executed in two stages, followed by water column correction and supervised classification. 

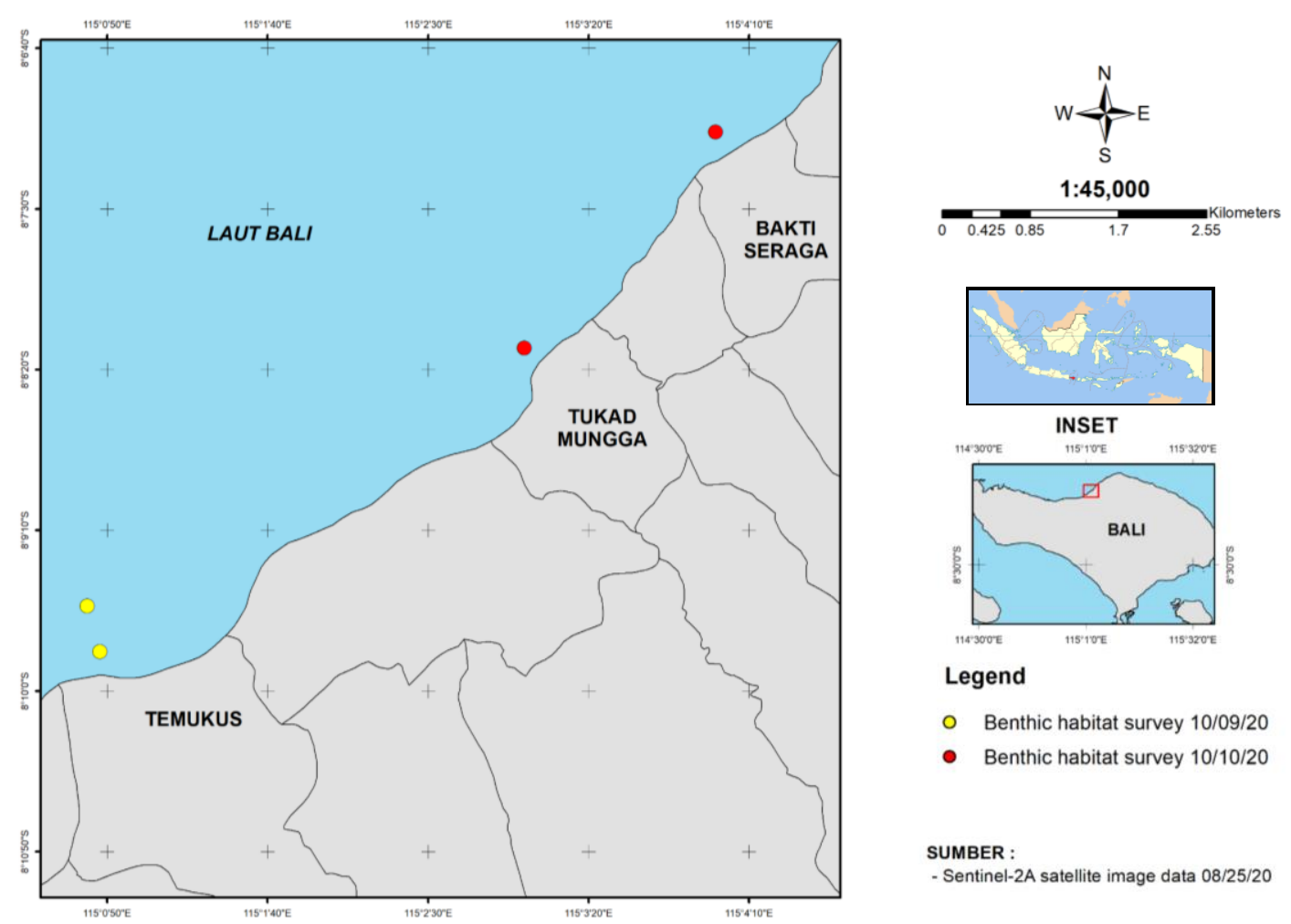

Legend

O Benthic habitat survey $10 / 09 / 20$

- Benthic habitat survey $10 / 10 / 20$

SUMBER :

- Sentinel-2A satellite image data 08/25/20

Figure 1. Location of research and sampling of photo transect habitat (source: Sentinel-2A satellite image data 08/25/20)

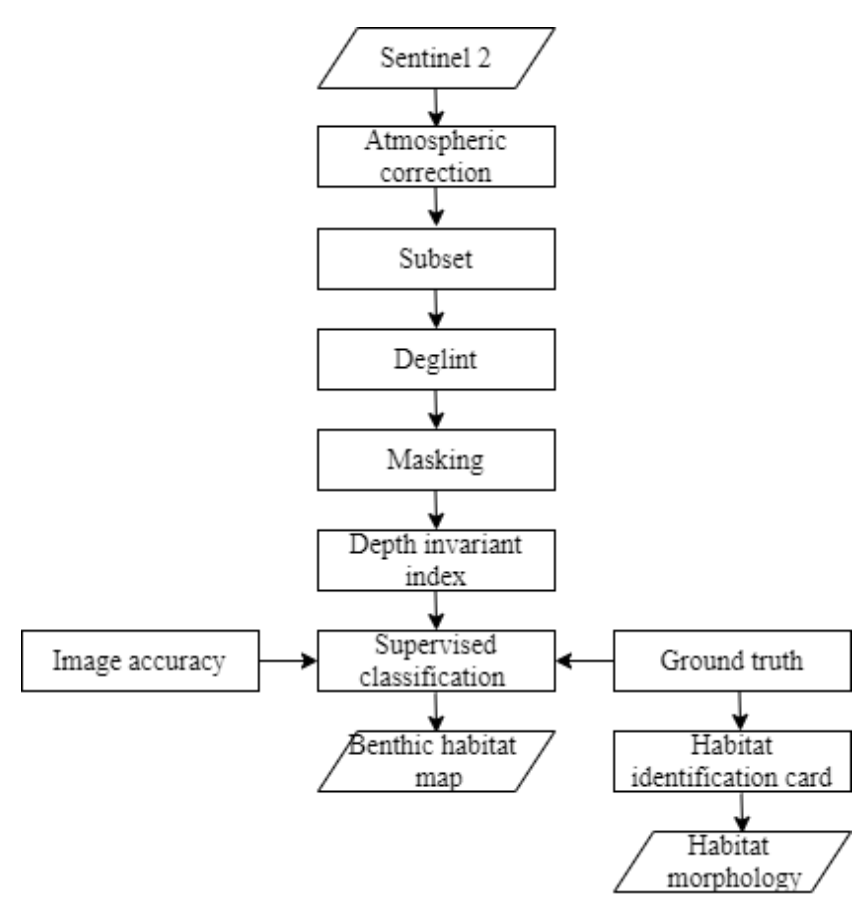

Figure 2. Research flowchart 1

Water column correction, also called the Depth Invariant Index (DII) developed by Lyzenga (1981) is carried out to obtain information on underwater objects. The method developed by lyzenga already exists in the Sen2Coral toolbox in SNAP. The Sen2Coral toolbox has been developed in the scope of the ESA SEON Programme Sen2Coral the objective of which is the scientific exploitation and validation of Sentinel-2 imagery for coral reef mapping (habitat, bathymetry and water quality) and change monitoring. The formation of a new image using the Lyzenga (1981) algorithm method combines two visible light bands. In this study, the water column correction used a green-red (B2B3) band combination on the Sentinel-2A image. The equation used in this method is as follows (Lyzenga 1981; Green et al. 2000):

$$
\begin{aligned}
& D I I=\ln \left(L_{i}\right)-\left[\left(\frac{k_{i}}{k_{j}}\right) \ln \left(L_{j}\right)\right] \\
& \frac{k i}{k j}=a+\sqrt{\mathrm{a}^{2}+1} ; a=\left(\sum_{i i}-\sum_{i j}\right) / 2 \sum_{i j}
\end{aligned}
$$

Where: DII: Depth Invariant Index, Li: digital value in band $\mathrm{i}, \mathrm{Lj}$ : digital value in band $\mathrm{j}, \mathrm{Ki} / \mathrm{kj}$ : the ratio of the attenuation coefficient in the band pairs $\mathrm{i}$ and $\mathrm{j}, \Sigma \mathrm{ii}, \mathrm{jj}$ : variant band i, or band j, $\Sigma \mathrm{ij}$ : covarian band ij.

The attenuation coefficient value is obtained by creating a region of interest $(\mathrm{ROI})$ in an area with a homogeneous base substrate and is found at different depths. ROI determined Based on visual interpretation and underwater photo information. After correcting the water column (Figure 3), then the image classification is carried out using the supervised classification maximum likelihood method with SNAP (Sentinel Aplication Platform) (Table 1), by taking samples of each digital value grouped according to certain classifications, which are then used as the basis for the algorithm for calculating digital value classification (Jensen 1996). 
Table 1. Habitat area in Lovina Area

\begin{tabular}{lccc}
\hline \multirow{2}{*}{ Habitat } & Temukus & $\begin{array}{c}\text { Tukad } \\
\text { Mungga }\end{array}$ & Baktiseraga \\
\cline { 2 - 4 } & Area (ha) & Area (ha) & Area (ha) \\
\hline Sand & 5.61 & 1.43 & 1.36 \\
Seagrass & 8.42 & 5.53 & 7.72 \\
Coral & 29.48 & 8.69 & 11.37 \\
Rubble & 8.1 & 4.09 & 3.58 \\
Reef slope & 7.54 & 3.72 & 3.13 \\
Intertidal zone & 2.19 & 1.71 & 0.72 \\
Total area (ha) & 61.34 & 25.17 & 27.88 \\
\hline
\end{tabular}

To perform object-based analysis with the most commonly used mapping approach in coral reef environments is the supervised classification (Phinn et al. 2012). The principle of this classification is to classify the pixels in the image into certain classes based on the region of interest created from field data. The ROI dataset has been splitted evenly for training and validation purposes. The field survey was conducted as a process for testing the accuracy of the results of the supervised classification of Sentinel-2A satellite imagery and analysis of benthic habitats based on transect photographs. Field data were collected using a medium-scale approach (MSA) and quadrant estimation of $5 \times 5 \mathrm{~m}$ and saw the benthic cover (Clua et al. 2006). This technique was applied by Ampou et al. (2018) to study the Coral Reef in Menjangan Island. Ampou et al. (2018b) also applied the same technique to study Coral Reefs on Bunaken Island using higher resolution satellite imagery. Each result of the selection of similar habitat transect photographs is categorized into one habitat (representative). After processing the image data to obtain information in the form of a benthic habitat map, a benthic habitat analysis is performed from the transect photos of the coral reef habitat. The photo transfect was analyzed visually with a habitat identification card (Figure 5) to see rugosity, growth form, and dominant species (Andréfouët 2014; Andréfouët 2016). Rugosity is one approach to measure the complexity of a habitat (Du Preez 2014). The rugosity scale ranges from $0-5$, which indicates the variation level of surface elevation amplitude, in this case, coral reef habitat.

\section{Image accuracy}

The accuracy test was performed using a confusion matrix. The matrix compares the habitat classes from the image classification results with the actual classes from the field survey results. Three general parameters obtained from the error matrix are overall accuracy $(\mathrm{OA})$, producer's accuracy (PA), and user's accuracy (UA) (Green et al. 2000). Calculation of each accuracy is carried out with the following equation (Congalton and Green 2009):

$$
\begin{aligned}
& \text { Overall accuracy }=\frac{\sum_{i=1^{n i i}}^{k}}{n} \\
& \text { Producer accuracy }=\frac{n j j}{n+j}
\end{aligned}
$$

$$
\text { User accuracy } \quad=\frac{n i i}{n i+}
$$

Where: $k$ : number of rows in matrix, $n$ : number of observations, $n_{i i}$ : the number of observations in column $\mathrm{i}$ and row $\mathrm{i}, n_{j j}$ : the number of observations in column $\mathrm{j}$ and row j, $n_{i+}$ : total marginal row I, $n_{+j}$ : column total.

Kappa test was conducted to determine the values of two error matrices which were significantly different. $\mathrm{Z}$ statistics from the classification results with two other methods were calculated then pairwise comparison was performed to see the significance of each method. The values of 1 and 2 are Kappa statistical estimates of each error matrix. $\mathrm{Z}$ is the standardized value and the normal distribution (standard deviation). Statistical tests to find out if the two independent error matrices are significantly different are carried out using the equation:

$$
Z=\frac{k 1-k 2}{\sqrt{\operatorname{var} 1+\operatorname{var} k 2}}
$$

\section{RESULTS AND DISCUSSION}

\section{Results}

Based on supervised classification of benthic habitats in Temukus waters, Tukad Mungga waters, and Baktiseraga waters (Figure 3), have 6 classifications, sand, seagrass, coral, rubble, reef slope and intertidal zone. The total area of benthic habitat in the three locations is 114.39 ha. In Temukus waters, the total area of benthic habitat was the highest at 61.34 ha. Tukad Mungga waters have the lowest total area of 25.17 ha. Total habitat of the benthic area in Baktiseraga waters is not much different from Tukad Mungga waters with, 27.88 ha (Table 1).

Coral covers a plurality of benthic habitat in Temukus waters with 29.48 ha area or $48 \%$ of total area, while the intertidal zone is the smallest area with 2.19 ha or only $4 \%$ of the total area. Coral was also the most abundant habitat type in Tukad Mungga waters with 8.69 ha or $35 \%$ of total area, and the least abundant benthic habitat was sand which covers 1.43 ha or $6 \%$ of the total area. Coral was the most abundant benthic habitat type in Baktiseraga waters (Table 1 and Figure 4) with $11.37 \mathrm{Ha}$ or $41 \%$ of the total area, and the intertidal zone was the narrowest habitat type in this area with $0.72 \mathrm{Ha}$ or $3 \%$ of the total area.

Based on the results of the accuracy-test using the confusion matrix (Table 2), the overall accuracy (OA) is $60.28 \%$, and the kappa coefficient is 0.452 . The producer's accuracy (PA) and user's accuracy (UA) values range from 20\%-80\%. The highest producer's accuracy (PA) and user's accuracy (UA) values are found in coral, $89.89 \%$ and $69.57 \%$, respectively. At the same time, the lowest producer's accuracy (PA) value is located in the sand, with a PA value of $29.79 \%$. The most insufficient user's accuracy (UA) value is the intertidal zone, with a value of $42.62 \%$ 

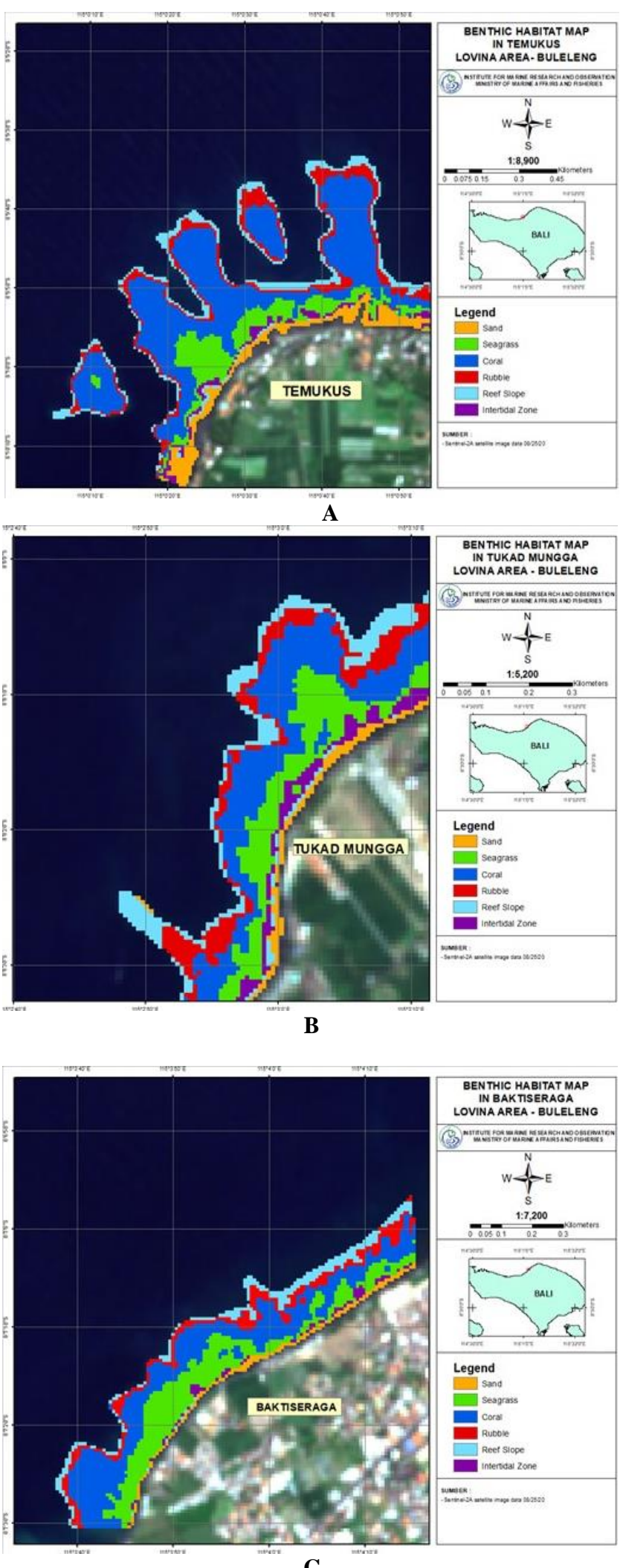

Figure 3. Benthic habitat map in Lovina, Buleleng, Indonesia: A Temukus, B. Tukad Mungga, C. Baktiseraga

Information that can be seen on the habitat identification card (Figure 5) in the form of genus name, percentage of coral, percentage of sand or rubble substrate, and rugosity. Temukus waters have a rugosity of 4 , and the predominant habitats are covered by genus Acropora, Isopora, Porites, Montipora and Pocillopora with rock, rubble, terrace and sand substrates. The waters of Tukad Mungga have a rugosity of 3 , and the dominant habitats are covered by genus Acropora, Montipora, Favia, Psammocora and Porites with rubble and sand as a substrate. Baktiseraga waters have rugosity 3 , and the dominant habitats are covered by genus Montipora sp, Goniastrea, Pavona, Platygyra, Pocillopora, Porites, Acropora, Leptoseris, Acropora, Pocillopora, and Fungia with rubble and sand substrates (Figure 6).

\section{Discussion}

Several researchers have conducted or compared the use of free access low-resolution satellite images and conclude that Sentinel-2 imagery is able to better map benthic habitats because it has a smaller pixel size (Hedley et al. 2018). Depth invariant index (DII) using the Lyzenga algorithm has been widely used in shallow water habitat mapping studies. Before using the algorithm, a comparison of the attenuation coefficients should be constructed from the relationship of the minimum substrate depth in two different bands (channels) (Lyzenga 1978 and Mumby et al. 1998). Maximum likelihood is the most common and widely used classification in supervised classification with remote sensing satellite imagery data. This algorithm groups unknown pixels based on the average vector and the matrix of each information class spectral pattern. Image pixels are included in one of the classes that have the highest probability (Tso and Mather 2009). This process resulted in the classification of shallow-water habitats based on color, consisting of sand (yellow), seagrass (green), coral (blue), debris (red), reef slopes (light blue), and intertidal zone (purple). The total area of habitat in Lovina waters, namely Temukus, Tukad Mungga, and Baktiseraga waters is 61.34 ha, 25.17 ha, and 27.88 ha respectively. Coral coverage in Temukus waters is around 29.48 ha or about $48 \%$. Meanwhile, the total coral coverage in Tukad Mungga waters was 8.69 ha or $35 \%$ and in Baktiseraga waters was 11.37 ha or $41 \%$. Several related studies conducted benthic habitats mapping using satellite imagery (Table 3). The results showed that satellite imagery is able to distinguish bottom habitats in shallow waters.

Based on the value of producer's accuracy (PA) and user's accuracy (UA) ranging from 20\%-80\% (Table 2), indicating that the benthic habitat class is challenging to map correctly. Sand and intertidal zone have the lowest PA and UA values. This shows that the benthic sand and intertidal zone habitat classes have not been mapped correctly. The accuracy test results showed that the total accuracy value (OA) was $60.28 \%$, with a kappa of 0.452 (Table 2). The accuracy level of Sentinel-2 imagery used for mapping benthic habitats in the Lovina area follows SNI 7716:2011, namely mapping benthic habitats in shallow waters that must have an accuracy of at least $60 \%$ (BIG 2014).

Based on Prasetia's research in 2011, the reef in Lovina area is generally categorized as a barrier reef type scattered 
at several points along Lovina waters. The coral condition in the Lovina area ranges from 18 to $44 \%$ of the live coral cover with bad to moderate category. Based on previous studies, the coral reef community structure of Lovina area consists of Acropora, Anacropora, Soft Coral, and
Sponge's formations. The Acropora group is generally in the form of branching, digitate, sub-massive, while the Anacropora group is generally in the form of branching, massive, encrusting, foliose, sub-massive, and mushroom.

Table 2. Confusion matrix data image

\begin{tabular}{|c|c|c|c|c|c|c|c|c|}
\hline \multicolumn{9}{|c|}{ Overall accuracy $=60.28 \% ;$ Kappa coefficient $=0.452$} \\
\hline Classified/reference & Sand & Seagrass & Coral & Rubble & Reef Slope & Intertidal zone & Total & $\mathbf{U A}(\%)$ \\
\hline Sand & 70 & 10 & 5 & 5 & 5 & 16 & 111 & 63.06 \\
\hline Seagrass & 50 & 90 & 15 & 15 & 10 & 20 & 200 & 45.00 \\
\hline Coral & 75 & 0 & 400 & 50 & 50 & 0 & 575 & 69.57 \\
\hline Rubble & 10 & 0 & 15 & 40 & 10 & 0 & 75 & 53.33 \\
\hline Reef slope & 10 & 0 & 10 & 15 & 28 & 0 & 63 & 44.44 \\
\hline Intertidal zone & 20 & 15 & 0 & 0 & 0 & 26 & 61 & 42.62 \\
\hline $\mathrm{PA}(\%)$ & 29.79 & 78.26 & 89.89 & 32.00 & 27.18 & 41.94 & & \\
\hline
\end{tabular}

Note:

UA coral $(\%) \quad=\quad 400 / 575 \times 100 \%=69.57 \%$

PA coral $(\%) \quad=400 / 445 \times 100 \%=89.89 \%$

Overall accuracy $(\%) \quad=(70+90+400+40+28+26) / 1085 \times 100 \%=60.28 \%$

Kappa coefficient $(\%) \quad=\left(\frac{[(654 \times 1085)-324606]}{\left(1085^{2}\right)-324606}\right) \times 100 \%=0,452 \%$

Table 3. Selected publication on mapping of benthic habitat using satellite imagery

\begin{tabular}{|c|c|c|c|c|c|}
\hline Reference & Location & Type of images & Objecive & Period & Method \\
\hline$\overline{\text { Phinn et al. (2012) }}$ & $\begin{array}{l}\text { Australia, Palau, } \\
\text { Fiji }\end{array}$ & Quickbird 2 & Benthic habitat mapping & 2004 & $\begin{array}{l}\text { Pixel-based and object-based } \\
\text { classification }\end{array}$ \\
\hline Saul et al. (2015) & Fiji & Worldview 2 & Coral reef habitat mapping & 2012 & Object-based image analysis \\
\hline Anggoro et al. (2018) & Pari Island & Worldview 2 & Benthic habitat mapping & 2012 & $\begin{array}{l}\text { Pixel-based and object-based } \\
\text { classification }\end{array}$ \\
\hline Wahidin et al. (2015) & North Maluku & Landsat 8 & $\begin{array}{l}\text { Coral reef benthic habitat } \\
\text { mapping }\end{array}$ & 2013 & Object-based image analysis \\
\hline El-askary et al. (2014) & Red Sea, Egypt & Landsat $5,7,8$ & Habitat changes & 2014 & Unsupervised classification \\
\hline Roelfsema et al. (2018) & Australia & Landsat 8 & Coral reef habitat mapping & 2014 & Object-based image analysis \\
\hline Ampou et al. (2018a) & Menjangan & Worldview 2 & Benthic habitat mapping & 2016 & Medium scale approach \\
\hline Hedley et al. (2018) & Lizard Island & $\begin{array}{l}\text { Sentinel-2A, } \\
\text { Landsat } 8\end{array}$ & Benthic habitat mapping & 2018 & Object-based image analysis \\
\hline
\end{tabular}
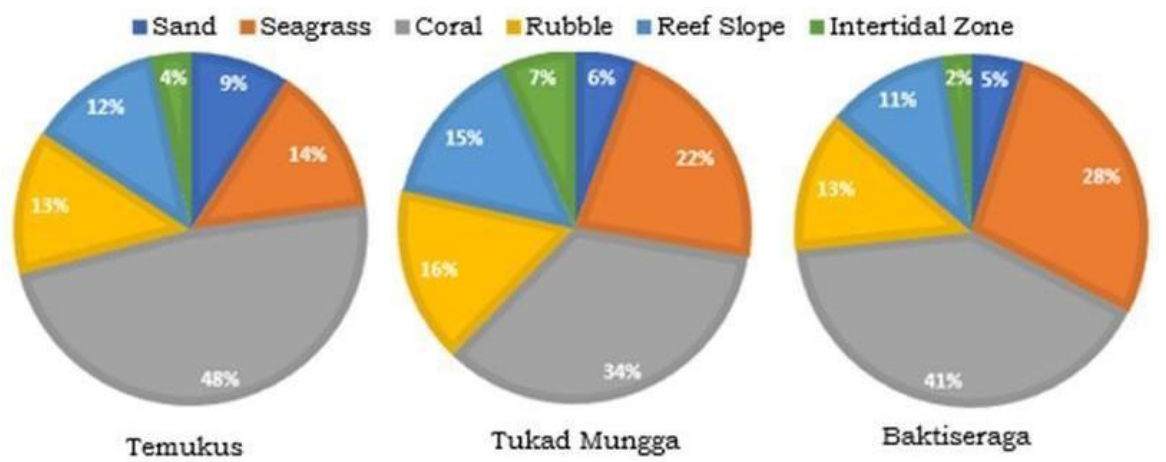

Figure 4. Percentage of benthic habitat cover 


\begin{tabular}{|c|c|c|c|c|c|c|c|c|c|}
\hline $\begin{array}{l}\text { Hard } \\
\text { coral }\end{array}$ & $\begin{array}{l}\text { Soft } \\
\text { coral }\end{array}$ & $\begin{array}{l}\text { Dead } \\
\text { coral }\end{array}$ & Algae & Seagrass & Sponge & Rubble & Terrace & Sand & $\begin{array}{l}\text { Mix } \\
\text { Other }\end{array}$ \\
\hline \multicolumn{3}{|c|}{ Reef flat } & \multicolumn{2}{|c|}{ Fore reef } & \multicolumn{2}{|c|}{ Reef slope } & \multicolumn{3}{|c|}{ Reef wall } \\
\hline
\end{tabular}

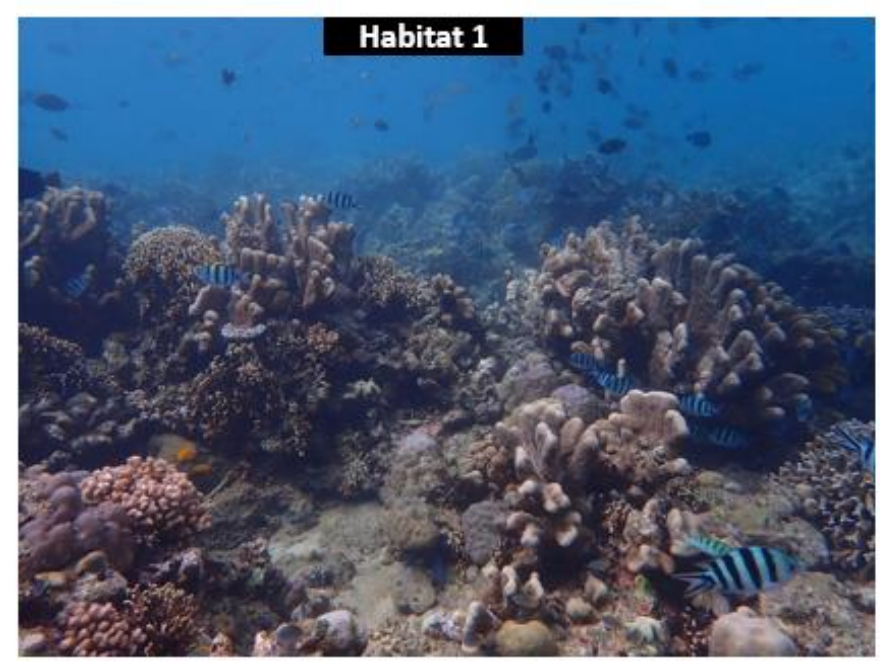

Hard coral:

Acropora, Isopora,

Porites, Montipora,

Pocillopora

$=80 \%$

\section{Substrat:}

Terrace $=20 \%$

Rugosity $=4$

Figure 5. An example of a habitat identification card at Lovina reef, Buleleng, Indonesia
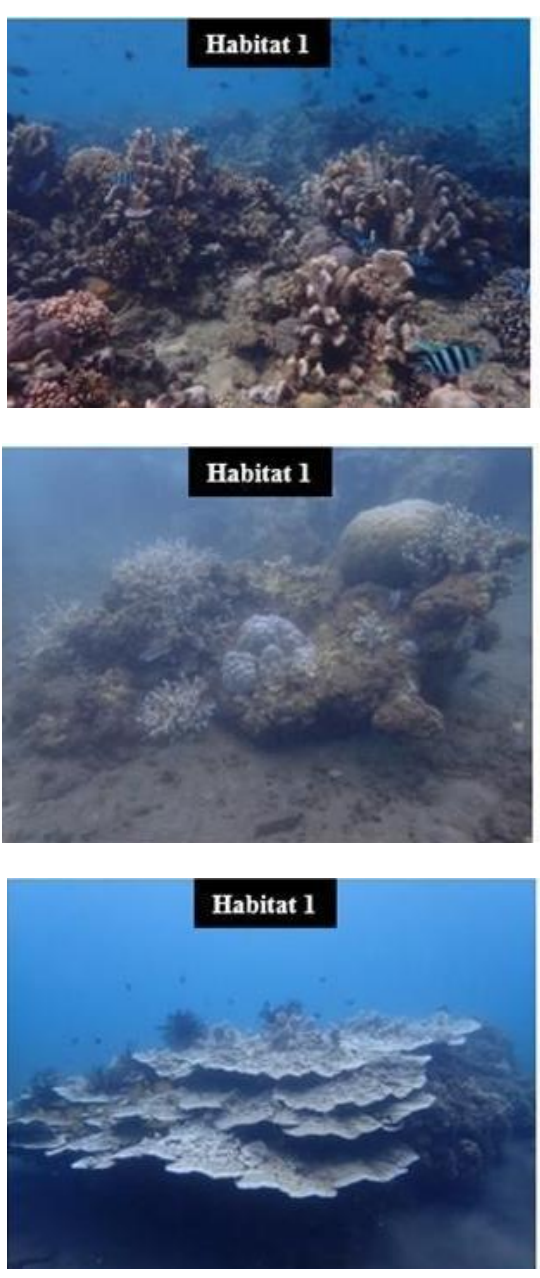

Figure 6. Habitat identification of the 3 habitat types in Lovina Area, Buleleng, Indonesia: A. Temukus, B. Tukad Mungga, C. Baktiseraga
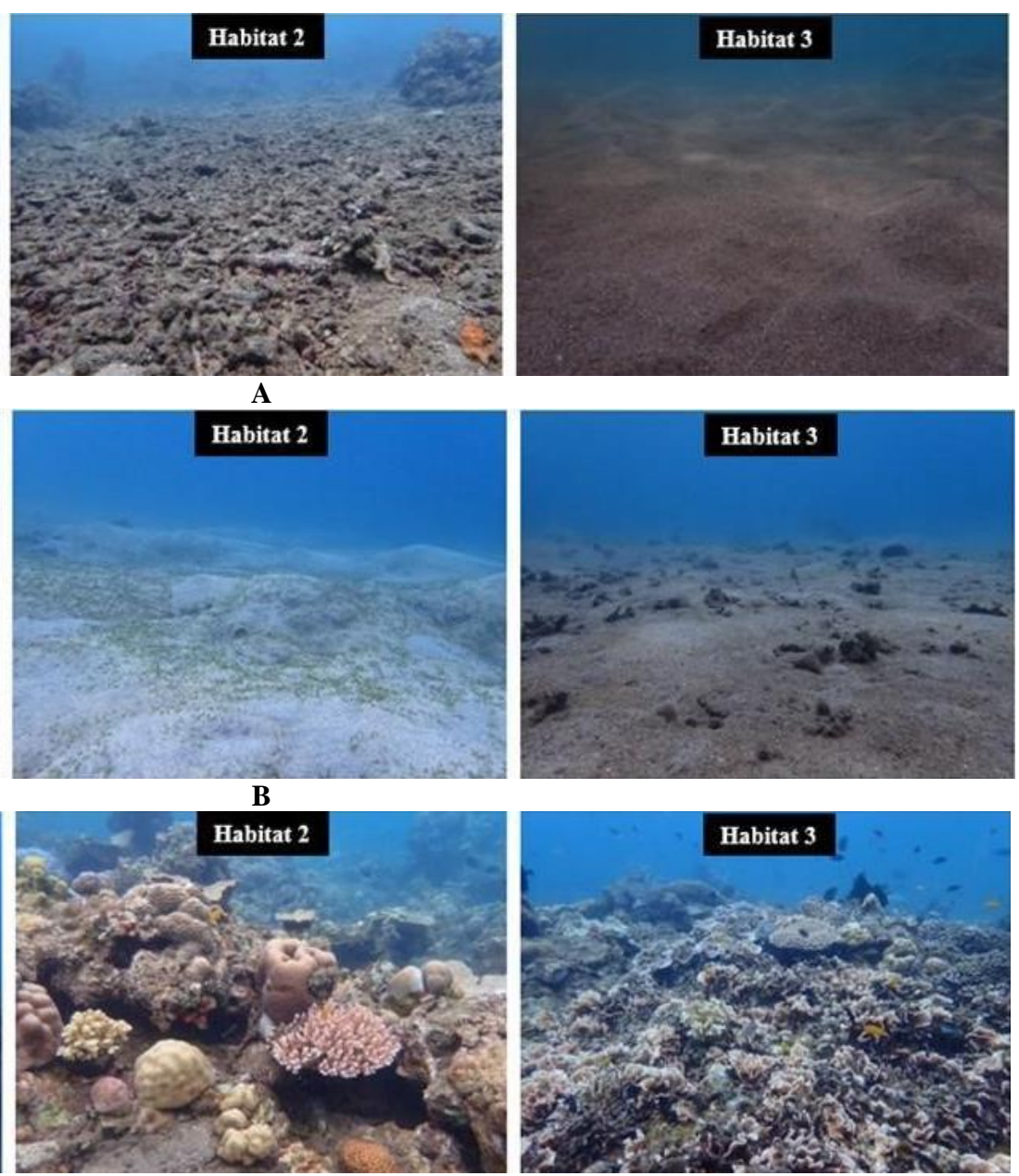

Rosity $=4$ 
Based on the visual analysis of benthic habitat types with the medium scale approach (MSA) technique from the transect photos, it can be seen that the live coral species that dominate Temukus waters have a rugosity of 4 , and the predominant habitats are covered by genus Acropora, Isopora, Porites, Montipora and Pocillopora with rock, rubble, terrace and sand substrates. The waters of Tukad Mungga have a rugosity of 3 , and the dominant habitats are covered by genus Acropora, Montipora, Favia, Psammocora and Porites with rubble and sand as a substrate. Baktiseraga waters have rugosity 3 , and the dominant habitats are covered by genus Montipora sp, Goniastrea, Pavona, Platygyra, Pocillopora, Porites, Acropora, Leptoseris, Acropora, Pocillopora, and Fungia with rubble and sand substrates (Figure 6). This habitat data can be used as a reference for the local government as a consideration regarding coral reef restoration areas in the Northern Bali Watershed. Based on analysis results that has been conducted, the area of coral reefs restoration can be selected. The coral reefs restoration will be located at flat slope and located near sandy substrate area or rubble area. Oftand muddy area has been avoided for artificial reefs site. This location has been selected based on safe construction of artificial reefs.

The limitation in this research is due to the conventional method of relying on the operator's ability to differentiate ROI in the satellite image. For future research, system automation can be developed for a faster and more accurate result.

\section{ACKNOWLEDGEMENTS}

The author would like to thank the staff of Ganesha University of Education, Indonesia and local stakeholder, the Food Security and Fisheries Agency, Buleleng District Government, Bali Province, Indonesia, that have assisted in field data. This research field data collection was funded by the PEN-Indonesia Coral Reef Garden (ICRG) Project.

\section{REFERENCES}

Ampou EE, Radiarta IN, Hanintyo R, Andréfouët S. 2018a. Pemetaan habitat bentik pada ekosistem terumbu karang di perairan Pulau Menjangan. Jurnal Kelautan Nasional 13 (3): 137-144. DOI: 10.15578/jkn.v13i3.6655. [Indonesia]

Ampou EE, Ouillon S, Andréfouët S. 2018b. Challenges in rendering coral triangle habitat richness in remotely sensed habitat maps: The case of Bunaken Island (Indonesia). Mar Pollut Bull 131: 72-82. DOI: 10.1016/j. marpolbul.2017.10.026.

Andréfouët S, Hamel MA. 2014. Tropical islands quick data gap analysis guided by coral reef geomorphological maps. Mar Pollut Bull 81: 191-199. DOI: 10.1016/j.marpolbul.2014.01.055.

Andréfouët S. 2016. Contribution à l'étude de La Biocomplexité Des Récifs Coralliens de l'Indo Pacifiqu: Le Cas Des Atolls. UMR ENTROPIE, IRD.

Anggoro A, Sumartono E, Siregar VP, Agus SB, Purnama D, Supriyono, Puspitosari DA, Listyorini T, Sulistyo B, Parwito. 2018. Comparing object-based and pixel-based classifications for benthic habitats mapping in Pari Islands. J Phys Conf Ser 1114: 012049. DOI: 10.1088/1742-6596/1114/1/012049

Asaad I, Lundquist CJ, Erdmann MV, Costello MJ. 2018. Delineating priority areas for marine biodiversity conservation in the Coral
Triangle. Biol Conserv 222: 198-211. DOI: 10.1016/j.biocon.2018.03.037.

Clua E, Legendre P, Vigliola L, Magron F, Kulbicki M, Sarramegna S, Labrosse P, Galzin R. 2006. Medium Scale Approach (MSA) for improved assessment of coral reef fish habitat. J Exp Mar Biol Ecol 333 (2): 2019-2030. DOI: 10.1016/j.jembe.2005.12.010.

Congalton RG, Green K. 2009. Assessing The Accuracy of Remotely Sensed Data Principles and Practices 2nd ed. CRC Press Indiana, United States.

Du Preez C. 2014. A new Arc-Chord Ratio (ACR) rugosity index for quantifying three-dimensional landscape structural complexity. Landsc Ecol 30: 181-192. DOI: 10.1007/s10980-014-0118-8.

El-Askary, Abd El-Mawla SH, Li J, El-Hattab MM, El-Raey M. 2014. Change detection of coral reef habitat using Landsat-5 TM, Landsat 7 ETM+ and Landsat 8 OLI data in the Red Sea (Hurghada, Egypt). Intl J Remote Sens 35: 2327-2346. DOI: 10.1080/01431161.2014.894656.

ESA. 2017. Sentinel-2 MSI Technical Guide. https://earth.esa.int/web/sentinel/technicalguides/sentinel-2-msi.

Geospasial BI. 2014. Peraturan Kepala Pedoman Teknis Pengimpulan dan Pengelolaan Geospasial Habitat Dasar Perairan Laut Dangkal (Issue c). Badan Informasi Geospasial, Jakarta. [Indonesia]

Green EP, Mumby PJ, Edwards AJ, Clark CD. 2000. Remote Sensing Handbook for Tropical Coastal Management. UNESCO, Paris.

Hedley JD, Harborne AR, Mumby PJ. 2005. Simple and robust removal of sun glint for mapping shallow-water benthos. Intl J Remote Sens 26: 2107-2112. DOI: 10.1080/01431160500034086.

Hedley JD, Roelfsema C, Koetz B, Phinn S. 2012. Capability of the sentinel 2 mission for tropical coral reef mapping and coral bleaching detection. Remote Sens Environ 120: 145-155. DOI: 10.1016/j.rse.2011.06.028.

Hedley JD, Roelfsema CM, Chollett I, Harborne AR, Heron SF, Weeks S, Skirving WJ, Strong AE, Eakin CM, Christensen TRL, Ticzon V, Bejerano S, Mumby PJ. 2016. Remote sensing of coral reefs for monitoring and management: A review. Remote Sens 8: 118-157. DOI: $10.3390 /$ rs8020118.

Hedley JD, Roelfsema C, Brando V, Giardino C, Kutser T, Phinn S, Koetz B. 2018. Coral reef applications of Sentinel-2: Coverage, characteristics, bathymetry and benthic mapping with comparison to Landsat 8. Remote Sens Environ 216: 598-614. DOI: 10.1016/j.rse.2018.07.014.

Hochberg EJ. 2003, Capabilities of remote sensors to classify coral, algae, and sand as pure and mixed spectra. Remote Sens Environ 85: 174189. DOI: $10.1016 / \mathrm{s} 0034-4257(02) 00202-\mathrm{x}$.

Jensen JR. 1996. Introductory Digital Image Processing: A Remote Sensing Perspective. Prentice-Hall Inc, New Jersey (US).

Leon J, Woodroffe. 2011. Improving the synoptic mapping of coral reef geomorphology using object-based image analysis. Intl J Geogr Inf Sci 25: 949-969. DOI: 10.1080/13658816.2010.513980.

Lyzenga DR. 1978. Passive remote-sensing techniques for mapping water depth and bottom features. Appl Opt 17: 379-383. DOI: 10.1364/AO.17.000379.

Lyzenga DR. 1981. Remote sensing of bottom reflectance and water attenuation parameters in shallow water using aircraft and Landsat data. Intl J Remote Sens 2: 71-82. DOI: 10.1080/01431168108948342.

Menandro PS, Bastos AC, Boni G, Ferreira LC, Vieira FV, Lavagnino AC, Diesing M. 2020. Reef mapping using different seabed automatic classification tools. Geosci 10 (2): $72 . \quad$ DOI: 10.3390/geosciences10020072.

Mumby PJ, Green AJ, Edwards AJ, Clark CD. 1998. Coral reef habitat mapping: How much detail can remote sensing provide. Mar Biol 130: 193-202. DOI: 10.1007/s002270050238.

Mumby PJ, Skirving W, Strong AE, Hardy JT, LeDrew EF, Hochberg EJ, Stumpf RP, David LT. 2003. Remote sensing of coral reefs and their physical environment. Mar Pollut Bull 48: 210-228. DOI: 10.1016/j.marpolbul.2003.10.031.

Phinn SR, Roelfsema CM, Mumbai PJ. 2012. Multi-scale, object-based image analysis for mapping geomorphic and ecological zones on coral reefs. Intl J Remote Sens 33: 3768-3797. DOI: 10.1080/01431161.2011.633122.

Porskamp P, Rattray A, Young M, Ierodiaconou D. 2018. Multiscale and hierarchical classification for benthic habitat mapping. Geosci 8 (4): 119. DOI: $10.3390 /$ geosciences 8040119.

Prasetia, Dodik IN. 2011. Rekrutmen Karang di Kawasan Wisata Lovina. Ganesha University of Education, Singaraja. [Indonesia] 
Roelfsema C, Phinn S, Jupiter S, Comley S, Albert S. 2013. Mapping coral reefs at reef to reef-system scales. $10 \mathrm{~s}-1000 \mathrm{~s} \mathrm{~km} 2$. using objectbased image analysis. Intl J Remote Sens 34: 6367-6388. DOI: 10.1080/01431161.2013.800660.

Roelfsema C, Kovacs E, Ortiz JC, Wolff NH, Callaghan D, Wetle M, Phinn S. 2018. Coral reef habitat mapping: A combination of basedimage analysis and ecological modelling. Remote Sens Environ 208: 27-41. DOI: 10.1016/j.rse.2018.02.005.

Saul S, Purkis S. 2015. Semi-automated object-based classification of coral reef habitat using discrete choice models. Remote Sens 7 (12): 15894-15916. DOI: 10.3390/rs71215810.

Tso B and Mather PM. 2009. Classification Methods for Remotely Sensed Data. Taylor and Francis Inc, New York.

Trzcinska K, Janowski L, Nowak J, Rucinska-zjadacz M, Kruss A, von Deimling JS, Pocwiardowski P, Tegowski J. 2020. Spectral features of dual-frequency multibeam echosounder data for benthic habitat mapping. Mar Geol 427: 106-239. DOI: 10.1016/j.margeo.2020.106239.

Wahidin N, Siregar VP, Nababan B, Jaya I, Wouthuyzen. 2015. Objectbased image analysis for coral reef benthic habitat mapping with several classification algorithms. Proc Environ Sci 24: 222-227. DOI: 10.1016/j.proenv.2015.03.029.

Wicaksono GG, Restu IW, Ernawati NM. 2019. Kondisi ekosistem terumbu karang di bagian barat Pulau Pasir Putih Desa Sumberkima, Kabupaten Buleleng, Provinsi Bali. Curr Trends Aquat Sci 2 (1): $37-$ 45. [Indonesia]

Yamano H, Goodman JA, Purkis SJ, Phinn SR. 2013. Multispectral applications. In: Goodman JA, Purkis SJ, Phinn SR (eds). Coral Reef Remote Sens 3. Springer, Dordrecht. 